\title{
Growth of the Silverside Atherinella brasiliensis in Tramandaí Estuary, Southern Brazil (Actinopterygii: Atherinopsidae)
}

\author{
Giovana Bervian and Nelson F. Fontoura
}

The growth of Atherinella brasiliensis (Quoy \& Gaimard, 1824) was studied through monthly samples taken at Tramandaí Lagoon, Imbé County, Rio Grande do Sul, Brazil. Animals were captured using a beach seine net. Length-weight relationships and age- growth curves for males and females were adjusted. The growth parameters of the von Bertalanffy growth formulae are $\mathrm{L}_{\text {inf }}=16.0$ and $\mathrm{k}=0.883$ for males and $\mathrm{L}_{\mathrm{inf}}=17.0$ and $\mathrm{k}=0.825$ for females. First reproduction occurred one year after recruitment. Once reaching maturity, adults of $A$. brasiliensis reproduced once more in the next spring with two-year-olds and disappeared soon after from size frequency distributions. A few captured animals showed a size compatible with an age of three years.

O crescimento de Atherinella brasiliensis (Quoy \& Gaimard, 1824) foi estudado através de amostras mensais na laguna de Tramandaí, Imbé, Rio Grande do Sul, Brasil. Os animais foram capturados com uma rede de arrasto de praia (picaré) de $15 \mathrm{~m}$ de comprimento, $3 \mathrm{~m}$ de altura e malha de $5 \mathrm{~mm}$ entre nós adjacentes. Relações peso/comprimento e curvas de crescimento em comprimento são ajustadas para machos e fêmeas. Os parâmetros da curva de crescimento de von Bertalanffy são $\mathrm{L}_{\text {inf }}=16,0 \mathrm{e}$ $\mathrm{k}=0,883$ para machos e $\mathrm{L}_{\text {inf }}=17,0$ e $\mathrm{k}=0,825$ para fêmeas. A primeira maturação ocorre um ano após o recrutamento. Uma vez atingida a maturidade, adultos de $A$. brasiliensis reproduzem mais uma vez na próxima primavera (com dois anos de idade) e desaparecem logo após nas distribuições de freqüências de comprimento. Poucos animais capturados apresentam tamanhos compatíveis com idade de três anos.

Key words: Atherinidae, Longevity, Life cycle, Life history.

\section{Introduction}

Atherinella brasiliensis (Quoy \& Gaimard, 1824) is a species of relatively small silverside when compared with some Odonthestes species, with adults reaching about $16 \mathrm{~cm}$ of total length. The species is distributed in estuarine waters from Venezuela to southern Brazil (Figueiredo \& Menezes, 1978). Although it has no commercial importance, A. brasiliensis is easily captured with hook-and-line by recreational fishermen. Especially during the summer, recreational fishermen stand side-by-side on the two bridges crossing the Tramandaí channel, capturing a large number of animals.

Studies on A. brasiliensis biology concern its relative abundance, distribution, reproduction and feeding habits at Patos Lagoon (RS) (Bemvenuti, 1987; 1990), and aspects of reproductive biology at Conceição Lagoon (SC) (Hostim-Silva et al., 1995) and Paranaguá Bay (PR) (Favaro et al., 2003). Paiva Filho \& Giannini (1990) studied the relative growth of the species at Santos Bay (SP), analyzing several morphometric relationships.
According to Bervian \& Fontoura (1997), in the Tramandaí estuarine system, A. brasiliensis reproduces from October to January, with greater frequency in November. Size at first maturity is estimated as $9.1 \mathrm{~cm}$ (total length), and the maximum recorded fecundity is 2050 mature oocytes.

Table 1 presents a list of 13 species of Atherinella with growth data compiled at FishBase website (Froese \& Pauly, 2007). Only species with available growth information are listed. The minor species of the genus is $A$. milleri with a maximumrecorded length of $5.5 \mathrm{~cm}$. Within the genus Atherinella, $A$. brasiliensis could be considered a large species, attaining 16 $\mathrm{cm}$ of total length. Instantaneous growth rates (Bertalanffy's k) range from 0.83 to 0.98 and life span from 2.9 to 3.4 years. The presented parameters are not the result of direct field research, but estimates through FishBase life history tool from maximum recorded lengths.

The aim of the present work was to provide field-based information concerning the growth and life history of the Brazilian silverside $A$. brasiliensis.

Faculdade de Biociências, Pontifícia Universidade Católica do Rio Grande do Sul, Av. Ipiranga 6681 C.P. 1429, 90619-900 Porto Alegre, RS, Brazil.nfontoura@pucrs.br 


\section{Materials and Methods}

Fish collections were made from August/1993 to July/1994, through monthly samples at Tramandaí Lagoon, Imbé County, Rio Grande do Sul, Brazil (295' S and 5007' W). Fishes were sampled using a beach seine net $15 \mathrm{~m}$ long, $3 \mathrm{~m}$ high and $5 \mathrm{~mm}$ in mesh size. Catch effort was variable, aiming to maximize the monthly number of captured animals. After being captured, animals were fixed (10\% formalin), weighed to nearest $0.1 \mathrm{~g}$ and measured (total length) to nearest $1.0 \mathrm{~mm}$. Measurements were made in the first month after capture. Gonads were analyzed using a stereomicroscope for gender identification. Small individuals with no clear gender status were classified as "small unidentified." Specimens of $A$. brasiliensis were deposited in the collection of Museu de Ciências e Tecnologia da PUCRS (MCP 15274).

The weight/length relationship was described according the allometric function $W=a \cdot L^{b}$, according to Ricker (1975), where $\mathrm{W}=$ weight; $\mathrm{L}=$ length; $\mathrm{a}=$ proportionality coefficient; $b=$ allometric coefficient. Aiming to minimize the bias of $\log$ transformation (Smith, 1993), equation parameters were estimated by the Levenberg-Marquardt algorithm using SPSS 11.5 based on data from 2458 females, 1738 males and 765 small unidentified animals. Considering the $\mathrm{H}_{0}$ hypothesis of no difference, a single allometric function was applied to all the data set (males, females and small unidentified). Each individual weight value was then converted into a residual from the predicted length-weight function. This powerful procedure makes it possible to compare any complex function, extracting bias from size and allometric growth patterns, where several data sets can be compared using simple one-way ANOVA, with Tukey's post hoc test.

Length growth curves were estimated for males and females from size-frequency distributions of bimonthly grouped data. Mean size of isolated age groups were estimated as a simple average of the captured animals. When overlapped, age group mean lengths were estimated using the software MIX (Macdonald \& Pitcher, 1979). Asymptotic length $\left(\mathrm{L}_{\text {inf }}\right)$ and instantaneous growth rate $(\mathrm{k})$ values were estimated by means of the minimal residual variance method,

Table 1. Growth parameters, life span and occurrence of species of the genus Atherinella. Data compiled at FishBase (Froese \& Pauly, 2007) using only species with growth data available.

\begin{tabular}{|c|c|c|c|c|c|}
\hline Species & $\begin{array}{l}\text { Max. } \\
\text { Size } \\
(\mathrm{cm})\end{array}$ & $\mathrm{k}$ & $\begin{array}{c}\mathrm{L}_{\mathrm{inf}} \\
(\mathrm{cm})\end{array}$ & $\begin{array}{c}\text { Life } \\
\text { Span } \\
\text { (years) }\end{array}$ & Occurrence \\
\hline A. milleri & 5.5 & 0.98 & 5.9 & 2.9 & Western Central Atlantic \\
\hline A. sardina & 5.5 & 0.98 & 5.9 & 2.9 & $\begin{array}{c}\text { Lakes of Nicaragua and } \\
\text { Costa Rica }\end{array}$ \\
\hline A. guatemalensis & 7.5 & 0.94 & 8.0 & 3.0 & Eastern Central Pacific \\
\hline A. eriarcha & 8.0 & 0.94 & 8.6 & 3.0 & Eastern Central Pacific \\
\hline A. chagresi & 9.0 & 0.92 & 9.6 & 3.1 & Western Central Atlantic \\
\hline A. nepenthe & 10.0 & 0.88 & 10.7 & 3.2 & Eastern Central Pacific \\
\hline A. nesiotes & 10.0 & 0.88 & 10.7 & 3.2 & Eastern Central Pacific \\
\hline A. panamensis & 11.0 & 0.87 & 11.7 & 3.2 & Eastern Central Pacific \\
\hline A. starksi & 11.0 & 0.87 & 11.7 & 3.2 & Eastern Central Pacific \\
\hline A. argentea & 11.1 & 0.89 & 11.8 & 3.2 & Eastern Central Pacific \\
\hline A. blackburni & 13.0 & 0.85 & 13.8 & 3.3 & Western Central Atlantic \\
\hline A. brasiliensis & 16.0 & 0.83 & 16.9 & 3.4 & Eastern South Atlantic \\
\hline A. pachylepis & 16.0 & 0.83 & 16.9 & 3.4 & Eastern Central Pacific \\
\hline
\end{tabular}

according to Gonçalves \& Fontoura (1999), using the MINIVAR.

To obtain a real age growth curve from the time presumed for recruitment (November, according Bervian \& Fontoura, 1997), the $t_{0}$ of the von Bertalanffy growth model was considered as zero and the age of the first age group in the December/January sample computed as 1 month ( 0.0833 year). Growth curve parameters were estimated with the modal progression of the first age group (group 0+) identified in August-September samples ( 0.75 year) and followed by a full year.

Using a MINIVAR spreadsheet, for a range of $\mathrm{L}_{\text {inf }}$ values with acceptable biological limits, the growth parameter $\mathrm{k}$ was estimated by the following equation: $\mathrm{k}=\sum\left[-\ln \left\{1-\left(\mathrm{L}_{\mathrm{t}} / \mathrm{L}_{\mathrm{inf}}\right)\right\} / \mathrm{t}\right] /$ $\mathrm{n}$; where: $\mathrm{k}$ is the instantaneous growth rate; $\mathrm{L}_{\mathrm{t}}$ is the mean total length $(\mathrm{cm})$ of the age group with presumed age $t$ (years); $\mathrm{L}_{\text {inf }}$ is the average maximum total length $(\mathrm{cm})$; and $\mathrm{n}$ is the number of length to age data pairs. The $\mathrm{L}_{\text {inf }}$ value is then selected that minimizes the residual variance: $\mathrm{S}^{2}=\sum\left[\left\{\mathrm{L}_{\mathrm{inf}}(1-\right.\right.$

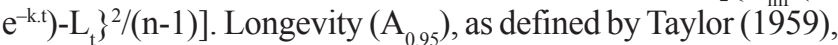
is the time for reaching $95 \%$ of the maximum average length $\left(\mathrm{L}_{\text {inf }}\right)$, and estimated as: $\mathrm{A}_{0.95}=0.996 / \mathrm{k}$.

\section{Results}

Length/weight relationships of $A$. brasiliensis for males, females and juveniles are shown in Fig. 1. Parameters of the adjusted functions are presented in Table 2, and the Tukey test results comparing weight residuals of males, females and small unidentified animals are presented in Table 3.

It is interesting to note that significant differences are observed when comparing males and females (Tukey's test, $\mathrm{p}=0.007$ ) or males and small unidentified animals (Tukey's test, $p=0.012$ ), while growth parameters are almost the same (Table 2) and no visual difference can be identified in Fig. 1, except that females attain larger sizes. This apparent contradiction results from a very large sample set and a powerful statistical approach, able to identify minimal differences among data sets. Nevertheless, for practical purposes only, a pooled growth model could be more useful.

Figures 2 and 3 present the size-frequency distributions of $A$. brasiliensis males and females. In Figs. 2 and 3, small

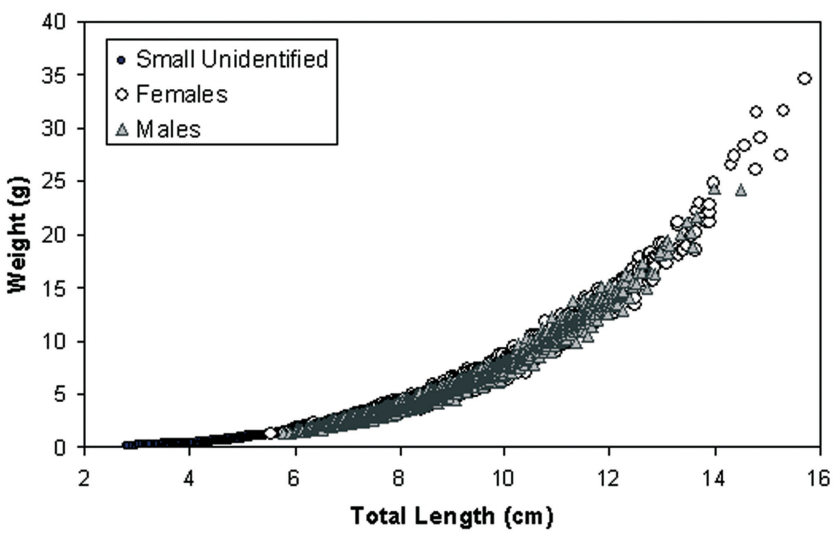

Fig. 1. Length/weight relationship of the silverside Atherinella brasiliensis in Tramandaí Estuary, Southern Brazil. 
Table 2. Parameter estimations for the length/weight relationships of Atherinella brasiliensis (a=proportionality coefficient; $\mathrm{b}=$ allometric coefficient).

\begin{tabular}{ccccccccc}
\hline & \multicolumn{2}{c}{ Small Unidentified } & \multicolumn{2}{c}{ Males } & \multicolumn{2}{c}{ Females } & \multicolumn{2}{c}{ Pooled Data } \\
\hline & Estimate & SE & Estimate & SE & Estimate & SE & Estimate & SE \\
\hline $\mathrm{a}$ & 0.00681 & 0.000190 & 0.00486 & 0.000105 & 0.00487 & 0.0000631 & 0.00490 & 0.0000563 \\
$\mathrm{~b}$ & 3.03 & 0.0148 & 3.20 & .00916 & 3.20 & 0.00545 & 3.20 & 0.00484 \\
$\mathrm{r}^{2}$ & 0.986 & & 0.987 & & 0.987 & & 0.989 & \\
\hline
\end{tabular}

Table 3. Tukey test comparison table for the length/weight residuals of Atherinella brasiliensis. * The mean difference is significant at the .05 level.

\begin{tabular}{|c|c|c|c|c|c|c|}
\hline \multirow[b]{2}{*}{ (I) SEX } & \multirow{2}{*}{\multicolumn{2}{|c|}{$\begin{array}{c}\text { Mean Difference } \\
(\mathrm{I}-\mathrm{J})\end{array}$}} & \multirow[b]{2}{*}{ Std. Error } & \multirow[b]{2}{*}{ Sig. } & \multicolumn{2}{|c|}{ 95\% Confidence Interval } \\
\hline & & & & & Lower Bound & Upper Bound \\
\hline Small & Females & .0115 & .01629 & .761 & -.0267 & .0497 \\
\hline Unidentified & Males & $.0488(*)$ & .01707 & .012 & .0088 & .0888 \\
\hline Females & Males & $.0373(*)$ & .01236 & .007 & .0084 & .0663 \\
\hline
\end{tabular}
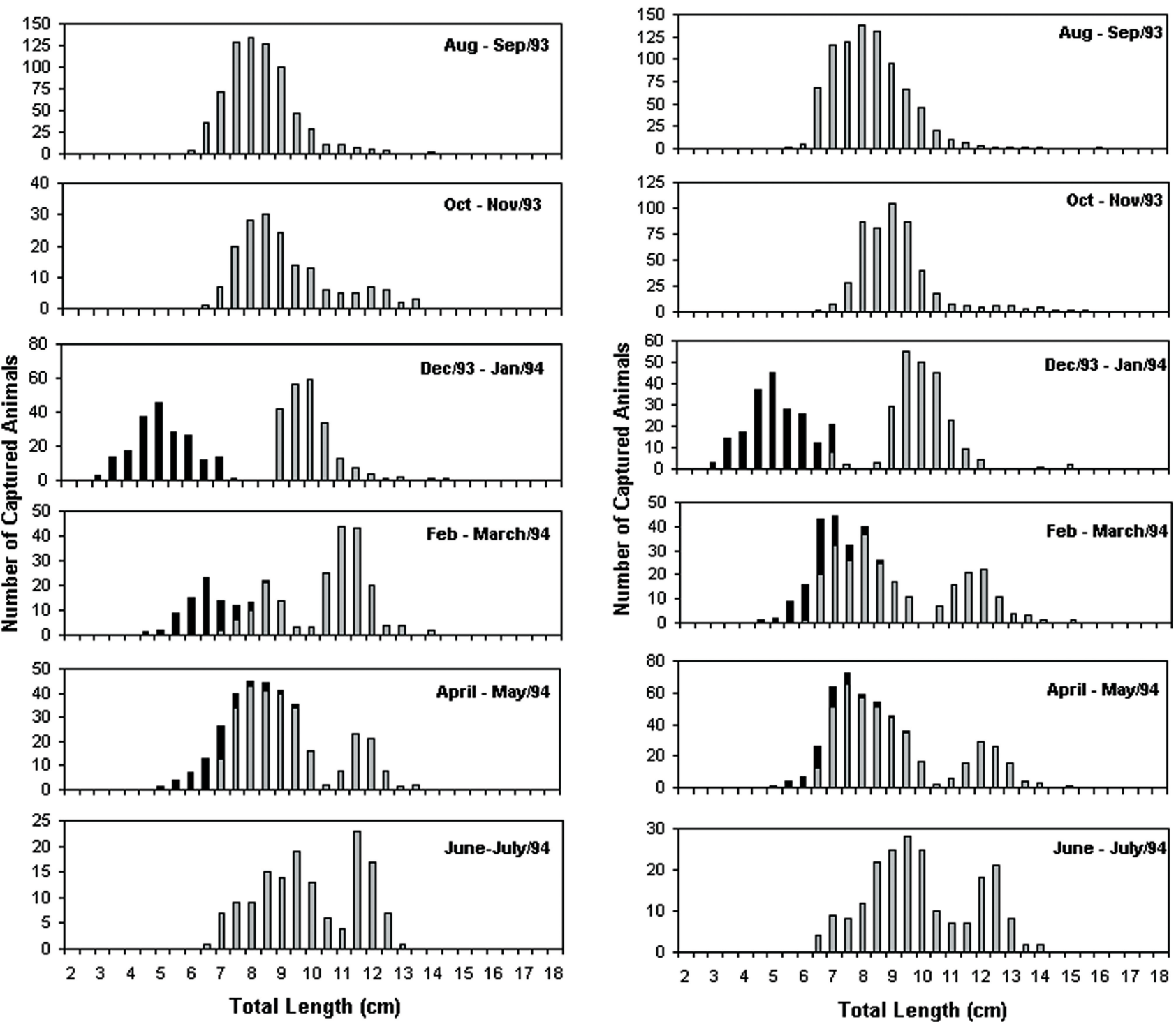

Fig. 2. Length frequency distributions of males of the silverside Atherinella brasiliensis in Tramandaí Estuary, Southern Brazil. Black bars represent small animals with no gender identification and equally distributed as males or females.

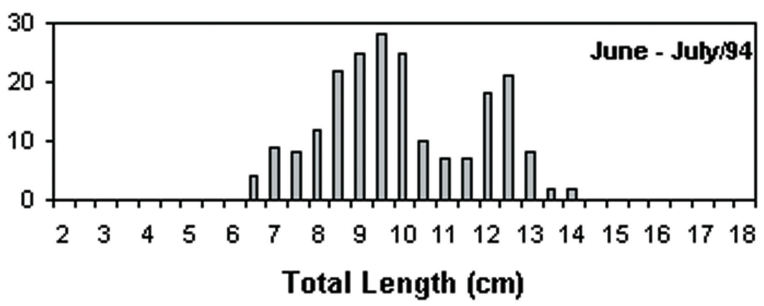

Fig. 3. Length frequency distributions of females of the silverside Atherinella brasiliensis in Tramandaí Estuary, Southern Brazil. Black bars represent small animals with no gender identification and equally distributed as males or females. 
animals with no gender identification are represented as dark bars, half of them computed as male and half as female. A clear modal progression can be observed. The age group zero appears in December/January with an approximate size of 5 $\mathrm{cm}$, growing up to about $8.5 \mathrm{~cm}$ in June/July (seven months) when this specific age group progression ends. Following August/September and October/November, when one year is completed, no size increment could be identified. In fact, age group average sizes decreased from June/July to August/ September samples. This abnormality results from two distinct facts. The age group 0 from June/July and September/October were born in different years, and average size results probably from quite distinct environmental parameters. On the other hand, the June to September period comprises the winter months, with expected reduction in growth rate (Fontoura \& Agostinho, 1996).

After completing one year, modal progression continues at least for one more year, when the animals reach a size of around $12 \mathrm{~cm}$ of total length and an age of two years. Few animals were captured with a size compatible with ages greater than two years. Table 4 presents the average size for each age group of males and females in a presumed series of modal progression. The age of the first modal group (December/ January) was computed as one month, since according to Bervian \& Fontoura (1997), the peak of reproductive activity occurs in November. As can be observed, females of the same presumed age group of males were larger. The largest captured female had $16.0 \mathrm{~cm}$ of total length, while the largest male was $14.4 \mathrm{~cm}$ long.

For growth curve adjustment, a series of continuous modal displacement was applied. As year to year growth histories could be a little different as pointed out above, only the data series from the same age group was considered: the series of modal displacement of the age group 0+ in August/September/ 93 sample until June/July/94. These data series are shown in bold font in Table 4. Although some information is lost by this approach, the resultant model describes the real growth pattern of single age group, not mixing information from animals growing and recruiting under different conditions.

Table 4. Average total length of males and females of Atherinella brasiliensis in a presumed series of modal progression (Figures 2 and 3). Age values are month from peak reproduction (November) as reported by Bervian \& Fontoura (1997). In italics is a progression series of the same age group, used for growth curve estimation.

\begin{tabular}{ccc}
\hline $\begin{array}{c}\text { Presumed Age } \\
\text { (Months) }\end{array}$ & \multicolumn{2}{c}{ Average Total Length $(\mathrm{cm})$} \\
Males & Females \\
\hline 1 & 4.89 & 4.94 \\
3 & 6.25 & 6.97 \\
5 & 6.60 & 7.61 \\
7 & 8.59 & 8.31 \\
\hline 9 & 7.90 & 7.90 \\
11 & 8.51 & 8.62 \\
13 & 9.56 & 9.83 \\
15 & 11.14 & 11.60 \\
17 & 11.91 & 12.02 \\
19 & 11.56 & 11.92 \\
\hline 21 & - & - \\
23 & 12.35 & - \\
\hline
\end{tabular}

Tables 5 (males) and 6 (females) present estimates of the instantaneous growth rate $(\mathrm{k})$ and longevity $\left(\mathrm{A}_{0.95}\right)$ as a function of different simulated values of the asymptotic length $\left(\mathrm{L}_{\text {inf }}\right)$. Best fit (minor residual variance) to the von Bertalanffy model was obtained when the asymptotic lengths (total length) of males and females were 16.0 and $17.0 \mathrm{~cm}$, respectively (Males: $\mathrm{k}=0.884 ; \mathrm{A}_{0.95}=3.4$; Females: $\mathrm{k}=0.825$; $\mathrm{A}_{0.95}=3.6$ ). Growth curves with minimal residual variance are presented in Fig. 5.
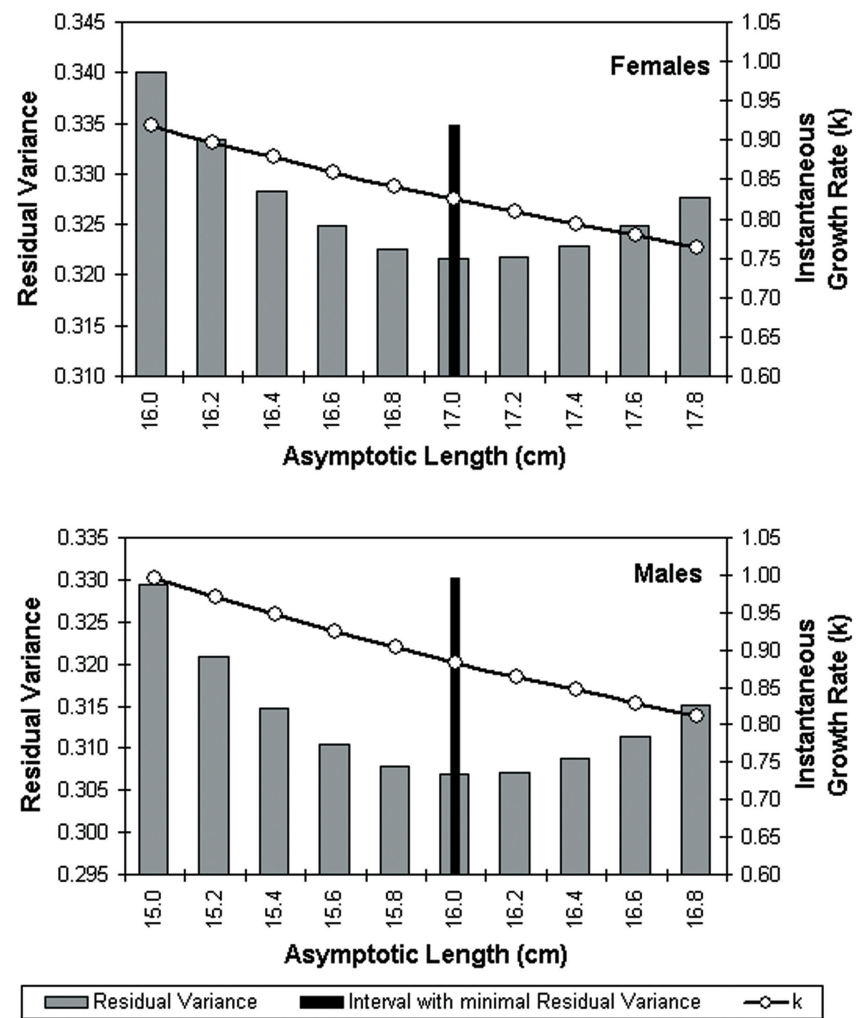

Fig. 4. Minivar plots to estimate growth parameters of the von Bertalanffy growth function for the silverside Atherinella brasiliensis in Tramandaí Estuary, Southern Brazil.

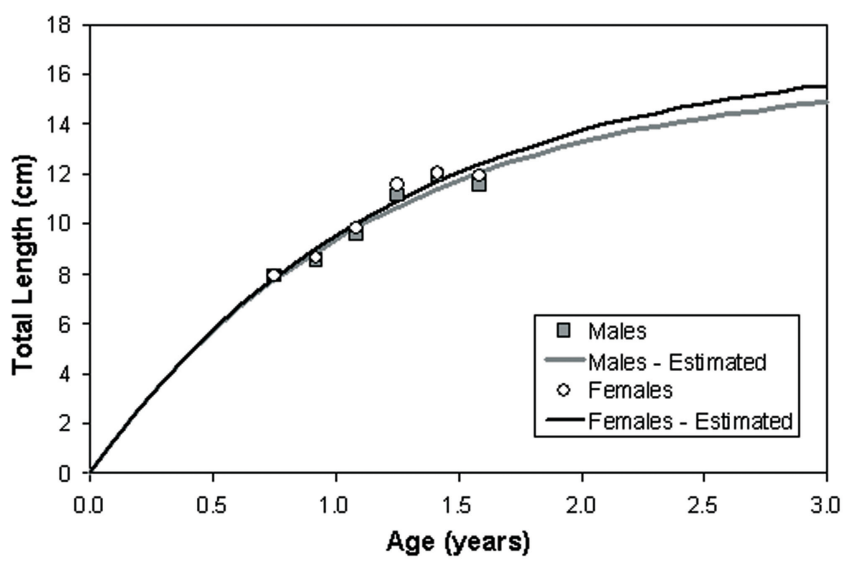

Fig. 5. Estimated von Bertalanffy growth curves for the silverside Atherinella brasiliensis in Tramandaí Estuary, Southern Brazil. 
Table 5. Parameters of von Bertalanffy growth formulae for Atherinella brasiliensis males in southern Brazil and residual variance with different simulated asymptotic lengths. Longevity estimates defined as the time (years) to attain $95 \%$ of the asymptotic length. In italics are the data that result in the best fit.

\begin{tabular}{cccc}
\hline Linf & $\begin{array}{c}\text { Residual } \\
\text { Variance }\end{array}$ & $\mathbf{K}$ & $\begin{array}{c}\text { Longevity } \\
\text { (years) }\end{array}$ \\
\hline 15.0 & 0.3295 & 0.996 & 3.0 \\
15.2 & 0.3210 & 0.971 & 3.1 \\
15.4 & 0.3147 & 0.947 & 3.2 \\
15.6 & 0.3104 & 0.925 & 3.2 \\
15.8 & 0.3078 & 0.904 & 3.3 \\
\hline $\mathbf{1 6 . 0}$ & $\mathbf{0 . 3 0 6 8}$ & $\mathbf{0 . 8 8 4}$ & 3.4 \\
\hline 16.2 & 0.3071 & 0.864 & 3.5 \\
16.4 & 0.3088 & 0.846 & 3.5 \\
16.6 & 0.3115 & 0.829 & 3.6 \\
16.8 & 0.3151 & 0.812 & 3.7 \\
\hline
\end{tabular}

\section{Discussion}

As shown in Table 2, the allometric coefficient (b) is different from the perfect cube $(b \neq 3 ; p<0.001)$ for males, females and grouped data, indicating that animals acquired more weight proportional to length during ontogenetic development. This same growth pattern was observed by Hostim-Silva et al. (1995) at Conceição Lagoon (SC), although at Santos (SP) the length/weight relationship was isometric (Paiva-Filho \& Giannini, 1990).

Bemvenuti (1987) reported that $A$. brasiliensis can reach about $10 \mathrm{~cm}$ within one year, attaining a maximum size of 16.0 $\mathrm{cm}$ and a maximum longevity of 2 years. A pattern of two age groups was also observed by Hostim-Silva et al. (1995) in Conceição Lagoon (SC), although the average size of the second age group, by direct comparison of the length frequency distribution, appeared to be smaller, with a total length of the largest captured animal equaling $13.3 \mathrm{~cm}$.

Merging the predicted growth pattern of $A$. brasiliensis with information concerning the reproduction of the species at Tramandaí (Bervian \& Fontoura, 1997), a clear picture of the life cycle for the species can be revealed. The peak of reproductive activity occurs in the spring (November). The size at first maturity occurs with $8-9 \mathrm{~cm}$ for females, when the animals are completing the first year. Animals continue to grow, reproducing once more at age two and with $12-13 \mathrm{~cm}$ of total length. The presence of some large animals $(14-16 \mathrm{~cm}$; males and females) suggests a third age group with maybe a maximum life span of three years, confirming the life span estimated as the age to attain $95 \%$ of maximum length $\left(\mathrm{A}_{0.95}\right)$.

The life cycle and growth of $A$. brasiliensis at Tramandaí $\left(30^{\circ} \mathrm{S}\right)$ and Patos Lagoon $\left(32^{\circ} \mathrm{S}\right)$ appear to be similar, although the species apparently attains a smaller length at Conceição Lagoon $\left(27.5^{\circ} \mathrm{S}\right)$. Nevertheless, different results were reported by Paiva-Filho \& Giannini (1990) in Santos $\left(24^{\circ} \mathrm{S}\right)$. These authors found only one modal class throughout the year and no animals larger than $13.2 \mathrm{~cm}$. The clear modal progression from around $4 \mathrm{~cm}$ in November to $12 \mathrm{~cm}$ in October (data from
Table 6. Parameters of von Bertalanffy growth formulae for Atherinella brasiliensis females in southern Brazil and residual variance with different simulated asymptotic lengths. Longevity estimates defined as the time (years) to attain $95 \%$ of the asymptotic length. In italics are the data that result in the best fit.

\begin{tabular}{cccc}
\hline Linf & $\begin{array}{c}\text { Residual } \\
\text { Variance }\end{array}$ & $\mathbf{K}$ & $\begin{array}{c}\text { Longevity } \\
\text { (years) }\end{array}$ \\
\hline 16.0 & 0.3401 & 0.918 & 3.3 \\
16.2 & 0.3333 & 0.898 & 3.3 \\
16.4 & 0.3283 & 0.878 & 3.4 \\
16.6 & 0.3248 & 0.860 & 3.5 \\
16.8 & 0.3226 & 0.842 & 3.6 \\
\hline $\mathbf{1 7 . 0}$ & $\mathbf{0 . 3 2 1 6}$ & $\mathbf{0 . 8 2 5}$ & $\mathbf{3 . 6}$ \\
\hline 17.2 & 0.3218 & 0.809 & 3.7 \\
17.4 & 0.3229 & 0.793 & 3.8 \\
17.6 & 0.3249 & 0.778 & 3.8 \\
17.8 & 0.3277 & 0.764 & 3.9 \\
\hline
\end{tabular}

Paiva-Fillho \& Giannini, 1990) suggests that in warmer waters the individuals grow up faster, reproducing within one year and disappearing soon after.

According to Bemvenuti (1987), A. brasiliensis is mainly captured in the estuarine area of the Patos Lagoon (RS) during the spring and summer, moving to the estuarine mouth in the fall and winter. In the present work, this kind of seasonal movement was not identified, as all the collections were carried out at just one sample site in the estuarine area of the Tramandaí Lagoon complex. Nevertheless, despite this simpler sampling design, animals of all size classes were captured throughout the year, as could be identified in Figs. 2 and 3.

Discussing the relatively small total length of $A$. brasiliensis captured at Santos, Paiva-Filho \& Giannini (1990) suggested the possible migration of larger/older animals out of the sampling area. Nevertheless, their collection program was carried out both inside and outside the estuarine area, and a biased sampling was probably not the cause of missing large animals. As is generally described in the literature, faster growth, smaller size and lower longevity are expected at decreasing latitudes (Taylor, 1959; Fontoura \& Agostinho, 1996). In this case, the growth parameters estimated by PaivaFilho \& Giannini (1990) for Santos are not discrepant, but expected for $A$. brasiliensis at lower latitudes.

Another point to be discussed concerns the methodology applied to adjust the von Bertalanffy growth curve. Although unusual, the applied methodology is interesting because asymptotic length, instantaneous growth rate and longevity are all interrelated parameters. In Tables 5 and 6 (and Fig. 4), each set of $\mathrm{L}_{\text {inf }}$, $\mathrm{k}$ and $\mathrm{A}_{0.95-}$ could be seen as a different hypothesis describing the life history of the species. As regression is a matter of balance, for a given data set, changing any equation parameter implies changing all the parameters to maintain balance. Nevertheless, when fitting a growth curve, only one result is usually provided: the one with the least squares. However, this statistical result may not necessarily describe the real growth pattern; it represents 
only a probabilistic growth hypothesis that results in a best fit to a given data set. In Tables 4 and 5, the residual variance will tell what hypothesis is best supported by the data, but a set of different growth hypotheses are also presented, with respective residual variances. This option to show a set of possible results is philosophical rather than statistical; aiming to remind the reader that estimated growth parameters with minimal residual variance is just a probabilistic hypothesis, not necessarily the true one.

Finally, it is amazing that the presumed life cycle parameters of $A$. brasiliensis, based on an intensive sampling program, fits very well to the general predictions made by FishBase life history tool, as presented in Table 1, where only the maximum recorded length was used as input information. As a rule, life history parameters, as predicted by general statistical models, should be viewed only as a first approximation when additional field-based data are not available. In this case, $A$. brasiliensis could be viewed as a special case, almost a book case, confirming that general models could be very useful, and do work.

\section{Literature Cited}

Bemvenuti, M. A. 1987. Abundância, distribuição e reprodução de peixes-rei (Atherinidae) na região estuarina da Lagoa dos Patos, RS, Brasil. Atlântica, 9(1): 5-32.

Bemvenuti, M. A. 1990. Hábitos alimentares de peixes-rei (Atherinidae) na região estuarina da Lagoa dos Patos, RS, Brasil. Atlântica, 12(1): 79-102.

Bervian, G. \& N. F. Fontoura. 2006. Statistical model of variable allometric growth: otolith growth in Micropogonias furnieri (Actinopterygii, Sciaenidae). Journal of Fish Biology, 68(1): 196-208

Bervian, G. \& N. F. Fontoura. 1997. Reprodução de Atherinella brasiliensis no estuário do rio Tramandaí, Imbé, Rio Grande do Sul, Brasil (Teleostei, Atherinopsidae). Biociências, 5(2): 19-32.
Favaro, F. F., S. C. G. Lopes \& H. L. Spach. 2003. Reprodução do peixe-rei, Atherinella brasiliensis (Quoy \& Gaimard) (Atheriniformes, Atherinidae), em uma planície de maré adjacente à gamboa do Baguaçú, Baía de Paranaguá, Paraná, Brasil. Revista Brasileira de Zoologia, 20(3): 501-506.

Figueiredo, J. L. \& N. A. Menezes. 1978. Manual de peixes marinhos do sudeste do Brasil. II Teleostei (I). Museu de Zoologia da USP, São Paulo, 110p.

Fontoura, N. F. \& A. A. Agostinho. 1996. Growth with seasonally varying temperatures: an expansion of the von Bertalanffy growth model. Journal of Fish Biology, 48: 569-584.

Froese, R. \& D. Pauly. Eds. 2007. FishBase. World Wide Web electronic publication. Available in the World Wide Web at: http://www.fishbase.org.

Gonçalves, P. L. \& N. F. Fontoura. 1999. Dinâmica populacional de Palaemonetes argentinus na lagoa Fortaleza, Rio Grande do Sul, Brasil (Decapoda, Palaeminidae); Iheringia, Série Zoologia, 86: 171-186.

Hostim-Silva, M., L. Clezar, G. C. Ribeiro \& C. Machado. 1995. Estrutura populacional de Xenomelaniris brasiliensis (Quoy \& Gaimard, 1824) na Lagoa da Conceição, SC. Brazilian Archives of Biology and Technology, 38 (3): 949-960.

Macdonald, P. D. M. \& T. J. Pitcher. 1979. Age-groups from sizefrequency data: a versatile and efficient method of analyzing distribution mixtures. Journal of the Research Board of Canada, 36: 987-1001.

Paiva-Filho, A. \& R. Giannini. 1990. Contribuição ao conhecimento da biologia do peixe-rei Xenomelaniris brasiliensis (Quoy \& Gaimard, 1824) (Atherinidae), no complexo baía-estuário de Santos e São Vicente, Brasil. Boletim do Instituto Oceanográfico, 38(1): 1-9.

Ricker, W. E. 1975. Computation and interpretation of biological statistics of fish populations. Bulletin Fisheries Research Board of Canada, 191: 1-382.

Smith, R. J. 1993. Logarithmic transformation bias in allometry. American Journal Physical Anthropology, 90: 215-228.

Taylor, C. C. 1959. Temperature and growth - the Pacific Razor Clam. Journal du Conseuil, 25:93-101.

Submitted April 2007 Accepted September 2007 